\title{
NISBAH KELAMIN DAN UKURAN PERTAMA MATANG GONAD KERANG LUMPUR Anodontia edentula, LINNAEUS 1758 DI PULAU TOBEA, KECAMATAN NAPABALANO KABUPATEN MUNA
}

\author{
Rochmady*, Sharifuddin Bin Andy Omar**, dan Lodewyck S. Tandipayuk ${ }^{* *}$ \\ "Staf Pengajar STIPertanian Wuna Raha, e-mail : kampo.mokesano@gmail.com \\ ${ }^{* *}$ Staf Pengajar FKIP, Universitas Hasanuddin, Makassar, e-mail : -
}

\begin{abstract}
ABSTRAK
Penelitian dilakukan di Pulau Tobea dengan tujuan untuk menganalisis nisbah kelamin dan ukuran pertama matang gonad kerang lumpur. Data dianalisis untuk mengetahui nisbah kelamin dan ukuran pertama matang gonad kerang lumpur Pulau Tobea dengan menggunakan analisis chi-square $\left(\chi^{2}\right)$ dan Metode SpearmenKarber (Udupa, 1986). Hasil analisis nisbah kelamin dengan menggunakan chisquare berdasarkan stasiun pengambilan sampel, waktu pengambilan dan tingkat kematangan gonad (TKG) menunjukkan nisbah kelamin jantan kerang lumpur lebih sedikit dibandingkan dengan jenis kelamin betina. Hal ini ditunjukkan dengan nilai chi-square hitung > chi-square tabel baik berdasarkan waktu pengambilan sampel $(6,3700>4,3027)$, berdasarkan stasiun pengamatan $(6,6673>4,3027)$, berdasarkan tingkat kematangan gonad (TKG) $(6,6673$ > 4,3027). Ukuran pertama matang gonad kerang lumpur, jenis kelamin jantan mencapai ukuran matang gonad rata-rata panjang cangkang sebesar 39,62 mm, pada kisaran panjang cangkang sebesar 39,20-40,04 mm. Untuk jenis kelamin betina mencapai ukuran pertama matang gonad rata-rata panjang cangkang sebesar 39,58 mm, pada kisaran panjang cangkang sebesar 39,21-39,96 mm.

Kerang lumpur di Pulau Tobea, ukuran pertama matang gonad sebenarnya untuk jenis kelamin jantan mencapai ukuran panjang cangkang sebesar 39,7 mm dan jenis kelamin betina mencapai ukuran panjang cangkang sebesar 38,0 mm.
\end{abstract}

\section{Kata Kunci: Kerang lumpur Anodontia edentula, nisbah kelamin, Pulau Tobea}

\section{PENDAHULUAN}

\subsection{Latar Belakang}

Bivalvia (oysters, scallops, clams, cachles dan mussels) merupakan salah satu potensi sumberdaya penting di Indonesia, karena pada kenyataannya hampir semua spesies kelas Bivalvia dapat dimanfaatkan untuk berbagai kebutuhan manusia meskipun hanya beberapa jenis bernilai ekonomis penting (Natan, 2008). Di Indo-Pasifik ditemukan kira-kira 17 famili Bivalvia yang terdapat di hutan mangrove, yakni Archidae, Ostridae, Isognomonidae, Anomiidae, Mytilidae, Corbiculidae, Tellinidae, Solenidae, Cultellidae, Laternulidae, Lucinidae, Pholadidae, Teredinidae, Asophidae, Psammobidae, Blancomidae, dan Veredinidae (Moore, 2006). Bivalvia menyebar di daerah mangrove jenis Avicenia, Rhizopora, Laguncularia, Conocarpus, dan lain-lain (Morton, 1983; Primavera, et al., 2002).

Di antara famili di atas, spesies Anodontia edentula (Linneaus, 1758) merupakan anggota famili Lucinidae yang menyebar pada daerah mangrove dan dapat dikonsumsi serta bernilai ekonomis sebagai sumber protein (Carpenter dan Niem, 1998; Natan, 2008; Rochmady, 2011). Di Filipina dan Thailand, A. edentula dikenal dengan nama imbaw (Lebata dan Primavera, 2001; Lebata, 2001; Milarez, 2005; Cichon, 2006). Di Indonesia, dikenal dengan nama kerang lumpur (Natan, 2008). Di kabupaten Muna, dikenal dengan nama ghiwo (Rochmady, 2011; Rochmady, et al 2011a; 2011b) (Gambar 1).

Diketahui kurang lebih $80 \%$ atau sekitar 8.000 dari spesies Bivalvia hidup di berbagai 
kedalaman pada semua lingkungan perairan laut dan sisanya di air tawar (Brusca dan Brusca, 2002). Bivalvia biasa juga disebut Pelecypoda (Yunani; pelecys = kapak; podos $=$ kaki) atau juga dikenal sebagai Lamellibranchia (Poutiers, 1998). Kebanyakan dari kelas Bivalvia atau Pelecypoda membenamkan diri dalam lumpur, baik pada lingkungan perairan laut maupun tawar (Brusca dan Brusca, 2002; Natan, 2008; Rochmady, 2011). A. edentula mendiami areal berlumpur dekat aliran sungai dan estuaria (Milarez, 2005; Cichon, 2006; Natan, 2008; Rochmady, 2011; Rochmady, et al 2011a; 2011b). Kebiasaan hidup A. edentula dengan membenamkan diri dalam lumpur (mudflat) pada kedalaman 28 - $50 \mathrm{~cm}$ secara berkelompok pada daerah mangrove di intertidal dan subtidal (Natan, 2008; Rochmady, 2011). A. edentula menyimpan bakteri pengoksidasi sulfur pada insangnya (Lebata, 2000; Meyer, et al., 2008). Sebagaimana halnya dikatakan Taylor dan Glover (2000, 2004 dan 2007) dan Cosel (2006), sehingga dapat digunakan sebagai biofilter (Lebata dan Primavera, 2001; Lebata, 2001). Selain itu, dengan mengkonsumsi daging kerang lumpur dapat meningkatkan kadar estradiol dalam darah pada manusia sehingga dapat memperlambat usia perimenopause pada wanita (Sjafaraenan, 2011).
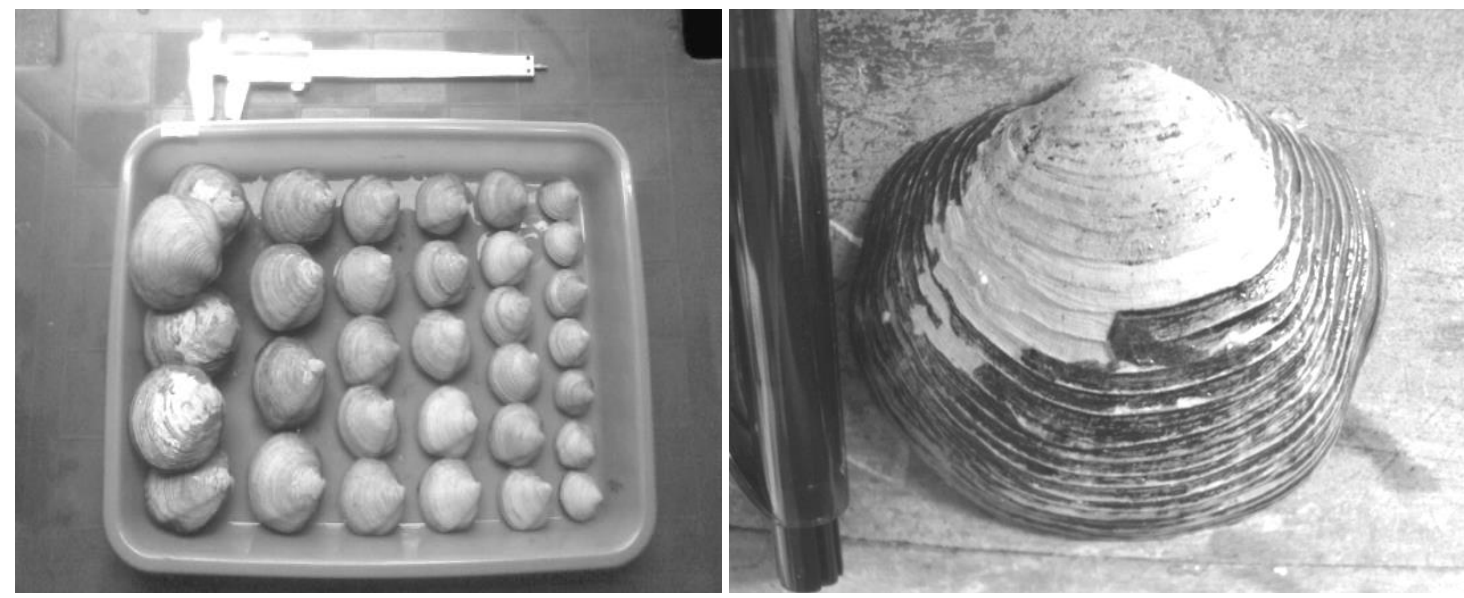

Gambar 1. Anodontia edentula Linnaeus, 1758 di Pulau Tobea, Kecamatan Napabalano, Kabupaten Muna (Rochmady, 2011).

Sebagaimana dilaporkan Taylor dan Glover (2007) bahwa kelas Bivalvia, khususnya famili Lucinidae, memiliki keanekaragaman tinggi dengan persebaran secara geografik dari Indo-Pasifik Barat hingga perairan Atlantik Barat pada lingkungan oligotropik, akan tetapi data biologi dan ekologinya tidak tersedia. Di Pulau Tobea, merupakan salah satu daerah dengan potensi kerang lumpur (Rochmady, 2011; Rochmady, et al 2011a; 2011b). Kerang lumpur A. edentula dimanfaatkan oleh masyarakat sekitar sebagai sumber protein hewani, dengan komposisi kandungan gizi yakni protein $7,182 \%$, karbohidrat $66,887 \%$, lemak $6,820 \%$, kolesterol 10,00 mg/dl, HDL, 6,00 mg/dl, Ca 263,385 ppm, $\mathrm{Cu}$ 9,107 ppm, Mg 28,467 ppm, Fe 1,859 ppm, dan LDL serta Zn konsentrasi tidak terdeteksi (Sjafaraenan, 2011). Persentase dan konsentrasi kandungan gizi yang dimiliki hampir sama jika dibandingkan dengan kandungan gizi kerang lumpur yang ada di daerah Teluk Ambon Dalam (TAD), dengan kadar air $80 \%$, protein $10,8 \%$, lemak $1,6 \%$, abu $0,75 \%$ dan karbohidrat $0,6 \%$ (Natan, 2008).

Pulau Tobea merupakan salah satu pulau yang berada di gugusan Kepulauan Tobea yang berada di sebelah utara Pulau Muna, kecamatan Napabalano (Rochmady, 2011). Kerang lumpur telah cukup lama dimanfaatkan secara tak terkendali oleh masyarakat lokal untuk dikonsumsi dagingnya (Rochmady, 2011). Aktifitas ini dikhawatirkan dapat mengakibatkan terjadinya penurunan populasi dan tingkat keragaman, bahkan dapat berdampak terhadap kepunahan (Natan, 2008).

Oleh karena itu, merupakan suatu hal yang penting untuk mengungkap informasi biologi reproduksi khususnya mengenai informasi nisbah kelamin dan ukuran pertama matang gonad kerang lumpur. Informasi yang diperoleh diharapkan dapat memberikan nilai tambah terhadap informasi kekerangan di Indonesia. 


\subsection{Tujuan Penelitian}

Penelitian dilaksanakan dengan tujuan untuk menganalisis :

1. Nisbah kelamin kerang lumpur yang terdapat di Pulau Tobea, Kecamatan Napabalano, Kabupaten Muna.

2. Ukuran pertama matang gonad kerang lumpur yang terdapat di Pulau Tobea, Kecamatan Napabalano, Kabupaten Muna.

\section{METODE PENELITIAN}

\subsection{Tempat dan Waktu}

Penelitian dilakukan di Pulau Tobea, Kecamatan Napabalano, Kabupaten Muna (Gambar 2). Pengambilan contoh dilakukan pada bulan Maret sampai bulan Mei 2011 dengan interval waktu koleksi contoh dilakukan sebulan sekali selama tiga bulan.

Pengukuran aspek reproduksi meliputi nisbah kelamin dan ukuran pertama matang gonad dilakukan di Laboratorium Budidaya Perairan, Jurusan Budidaya Perairan, Sekolah Tinggi Ilmu Pertanian Wuna, Raha.

\subsection{Alat dan Bahan}

Peralatan yang digunakan adalah roll meter dengan panjang $100 \mathrm{~m}$, patok plot dan tali rafiah serta alat tulis menulis. Untuk parameter biologi, peralatan yang digunakan adalah ember untuk menyimpan contoh kerang, kaliper dengan ketelitian 0,01 $\mathrm{mm}$ untuk mengukur panjang cangkang kerang. Dokumentasi penelitian dengan menggunakan kamera dan alat tulis menulis.

Untuk bahan yang digunakan dalam penelitian ini adalah kerang lumpur Anodontia edentula, Linnaeus 1758 yang diperoleh di lokasi penelitian.

\subsection{Prosedur Penelitian}

Koleksi contoh kerang lumpur dilakukan dengan menggunakan Metode Transek Garis (Line Transect Plot Method) yang ditentukan secara sengaja (purposive sampling) dengan arah tegak lurus terhadap garis pantai yang terdiri atas tiga plot (stasiun) pencuplikan. Pencuplikan kerang lumpur dilakukan untuk mewakili kategori daerah dekat pantai (Stasiun I), daerah peralihan (Stasiun II) dan daerah yang jauh dari pantai (Stasiun III), sepanjang transek garis yang dibuat dengan jarak interval $50 \mathrm{~m}$ pada masingmasing plot pencuplikan.

Koleksi contoh dilakukan pada saat surut terendah dengan cara menggali substrat sampai kedalaman $30 \mathrm{~cm}$ atau menggali lumpur hingga menemukan individu kerang lumpur. Selanjutnya hasil koleksi kerang lumpur disimpan dalam wadah ember.

Untuk membedakan kerang lumpur jenis kelamin jantan dan betina dilakukan dengan cara membedakan warna gonadnya yang terbungkus oleh viscera. Untuk mengukur panjang cangkang dilakukan menggunakan kaliper dengan ketelitian $0,01 \mathrm{~mm}$. Panjang cangkang yang diukur adalah jarak dari ujung anterior ke ujung posterior cangkang.

\subsection{Analisis Data}

\subsubsection{Nisbah kelamin}

Data yang terkumpul setiap pada waktu pengamatan dipisahkan menurut jenis kelamin, stasiun pengamatan dan tingkat kematangan gonad, dengan hipotesis sebagai berikut :

$\mathrm{H}_{0}$ : tidak ada perbedaan antara jumlah kerang jantan dan betina yang muncul (nisbah kelamin antara jantan dan betina adalah seimbang, yakni $1: 1$ )

$\mathrm{H}_{1}$ : terdapat perbedaan antara jumlah kerang jantan dan betina yang muncul.

Untuk menentukan nisbah kelamin dihitung dengan cara membandingkan jumlah kerang lumpur jantan dan betina. Nisbah kelamin dianalisa dengan uji Chi-Square $\left(\chi^{2}\right)$ dalam bentuk tabel kontigensi (Sugiyono, 2006) :

$$
\chi^{2}=\sum_{i=1,2,3}^{s} \frac{\left(f_{i}-\mathrm{F}\right)^{2}}{\mathrm{~F}}
$$

dimana $X^{2}=$ nilai distribusi kelamin, $f i=$ nilai pengamatan ke-i, $\mathrm{F}=$ nilai harapan ke-i, i adalah $1,2,3$, dan $\mathrm{S}=$ jumlah pengamatan.

Pada taraf kepercayaan 0,05 dengan nilai $\mathrm{X}_{\text {tabel }}^{2} \mathrm{db}(\mathrm{B}-1)$ dan (K-1) dimana B merupakan kategori baris dan $\mathrm{K}$ merupakan kategori kolom, dengan kriteria pengujian sebagai berikut :

$$
\begin{gathered}
\mathrm{H}_{0} \text { : diterima, } \mathrm{H}_{1} \text { : ditolak; apabila } \\
\mathrm{X}_{\text {hitung }}^{2} \leq \mathrm{X}_{\text {tabel }}^{2}(\alpha=0,05),
\end{gathered}
$$

$\mathrm{H}_{0}$ : ditolak, $\mathrm{H}_{1}$ : diterima; apabila

$$
X_{\text {hitung }}^{2}>X_{\text {tabel }}^{2}(\alpha=0,05) \text {. }
$$

\subsubsection{Ukuran pertama matang gonad}

Untuk mengetahui ukuran pertama matang gonad dilakukan sesuai dengan Metode Spearmen-Karber sebagaimana yang diusulkan oleh Udupa (1986), sebagai berikut :

$$
\mathrm{m}=\mathrm{Xk}+\frac{\mathrm{X}}{2}-\left\{\mathrm{X} \sum \mathrm{pi}\right\}
$$


Jika $\alpha=0,05$, maka batas-batas kepercayaan $95 \%$ dari m adalah :

$$
\operatorname{antilog}\left[m \pm 1,96 \sqrt{X^{2} \sum\left\{\frac{p_{i} \times q_{i}}{n_{i}-1}\right\}}\right]
$$

dimana $\mathrm{m}=$ logaritma panjang pada saat pertama kali matang gonad, $\mathrm{xk}=$ logaritma nilai tengah kelas panjang pada saat $100 \%$ matang gonad, $X=$ selisih logaritma nilai tengah, $\mathrm{pi}=$ proporsi matang gonad pada kelas ke-i (pi = ri/ni), ri = jumlah matang gonad pada kelas ke-i, ni = jumlah pada kelas ke-i, dan qi $=1-$ pi.

Dengan demikian raa-rata panjang cangkang kerang pada waktu mencapai kematangan gonad pertama kali adalah $\mathrm{M}=\operatorname{antilog} \mathrm{m}$.

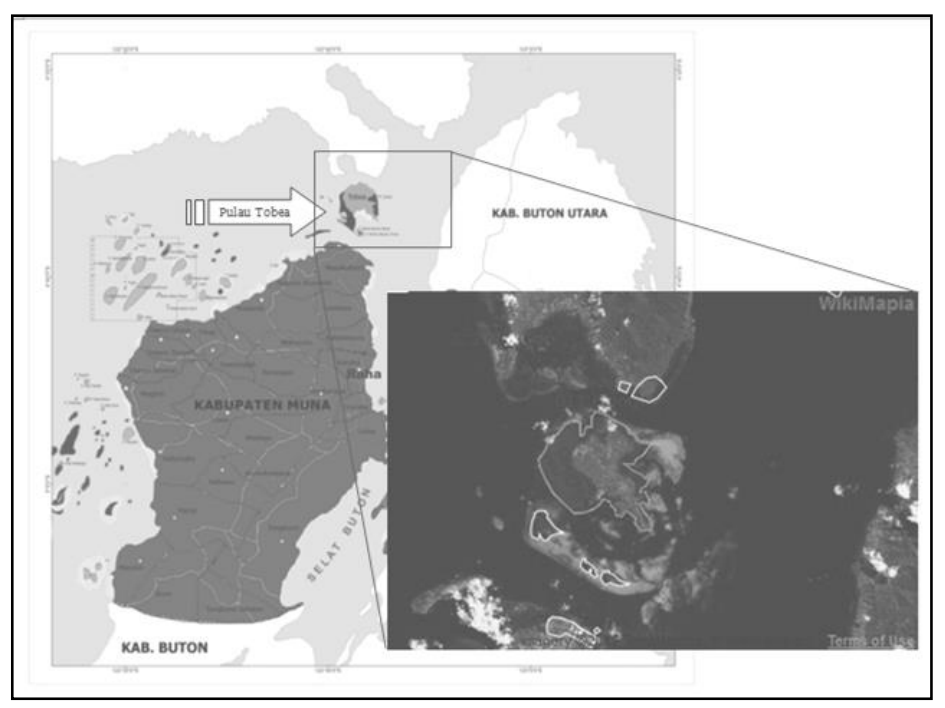

Gambar 2. Lokasi pengambilan contoh kerang lumpur Anodontia edentula Linnaeus, 1758 di pulau Tobea, kecamatan Napabalano, kabupaten Muna (Rochmady, 2011).

\section{HASIL DAN PEMBAHASAN}

Jumlah kerang lumpur yang berhasil dikoleksi selama penelitian di Pulau Tobea sebanyak 918 individu yang terdiri atas 415 jenis kelamin jantan dan 503 jenis kelamin betina.

\subsection{Nisbah kelamin}

Nisbah kelamin sebagai salah satu parameter reproduksi diukur untuk menentukan kemungkinan tersedianya induk jantan dan induk betina yang diharapkan dapat terjadi pemijahan. Dalam kondisi normal, rasio jenis kelamin jantan dan betina ditunjukkan dengan rasio jenis kalamin jantan dan betina antara satu (1) jantan berbanding satu (1) betina. Selain itu, nisbah kelamin dapat pula menunjukkan adanya eksploitasi yang berlebihan terhadap salah satu jenis kelamin maupun indikasi adanya perubahan lingkungan (Effendie, 1997).

Nisbah kelamin dihitung berdasarkan waktu pengambilan sampel yang dilakukan selama tiga bulan penelitian, yakni sejak bulan Maret sampai dengan bulan Mei. Hasil perhitungan Uji Chi-Square nisbah kelamin berdasarkan waktu pengambilan sampel (bulan) (Tabel 1 dan Gambar 3), berdasarkan tingkat kematangan gonad (TKG) (Tabel 2 dan Gambar 4), dan berdasarkan stasiun pengamatan (Plot) (Tabel 3 dan Gambar 5).

Tabel 1. Nisbah kelamin kerang lumpur (Anodontia edentula Linnaeus, 1758) jantan dan betina berdasarkan waktu pengambilan sampel (bulan) di Pulau Tobea, Kecamatan Napabalano, Kabupaten Muna.

\begin{tabular}{ccccc}
\hline Waktu Pengambilan Sampel & \multicolumn{2}{c}{ Jumlah Individu } & \multicolumn{2}{c}{ Nisbah Kelamin } \\
\cline { 2 - 5 } (bulan) & Jantan & Betina & Jantan & Betina \\
\hline Maret & 145 & 156 & 0,93 & 1,08 \\
April & 100 & 159 & 0,63 & 1,59 \\
Mei & 170 & 188 & 0,90 & 1,11 \\
\hline Jumlah & 415 & 503 & 0,82 & 1,26 \\
\hline
\end{tabular}




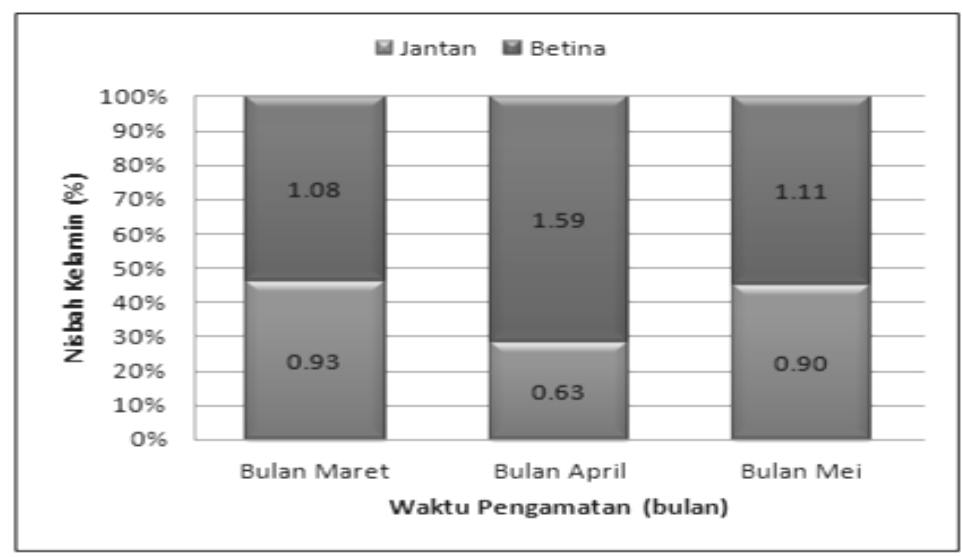

Gambar 3. Grafik nisbah kelamin kerang lumpur (Anodontia edentula Linnaeus, 1758) jantan dan betina berdasarkan waktu pengambilan sampel (bulan) di Pulau Tobea, Kecamatan Napabalano, Kabupaten Muna.

Berdasarkan waktu pengambilan sampel kerang lumpur nisbah kelamin jantan dan betina sebesar 0,82: 1,26 (Tabel 1 dan Gambar 3), hal ini ditunjukkan dengan nilai chi-square hasil perhitungan sebesar 6,3700. Hal ini berarti bahwa jumlah kerang lumpur jenis kelamin jantan lebih sedikit dibanding jenis kelamin betina pada setiap waktu pengambilan sampel.

Tabel 2. Nisbah kelamin kerang lumpur (Anodontia edentula Linnaeus, 1758) jantan dan betina berdasarkan tingkat kematangan gonad (TKG) di Pulau Tobea, Kecamatan Napabalano, Kabupaten Muna

\begin{tabular}{ccccc}
\hline \multirow{2}{*}{$\begin{array}{c}\text { Tingkat kematangan gonad } \\
\text { (TKG) }\end{array}$} & \multicolumn{2}{c}{ Jumlah Individu } & \multicolumn{2}{c}{ Nisbah Kelamin } \\
\cline { 2 - 5 } & Jantan & Betina & Jantan & Betina \\
\hline I & 30 & 11 & 2,73 & 0,37 \\
II & 110 & 105 & 1,05 & 0,95 \\
III & 190 & 236 & 0,81 & 1,24 \\
IV & 85 & 151 & 0,56 & 1,78 \\
\hline Jumlah & 415 & 503 & 1,29 & 1,08 \\
\hline
\end{tabular}

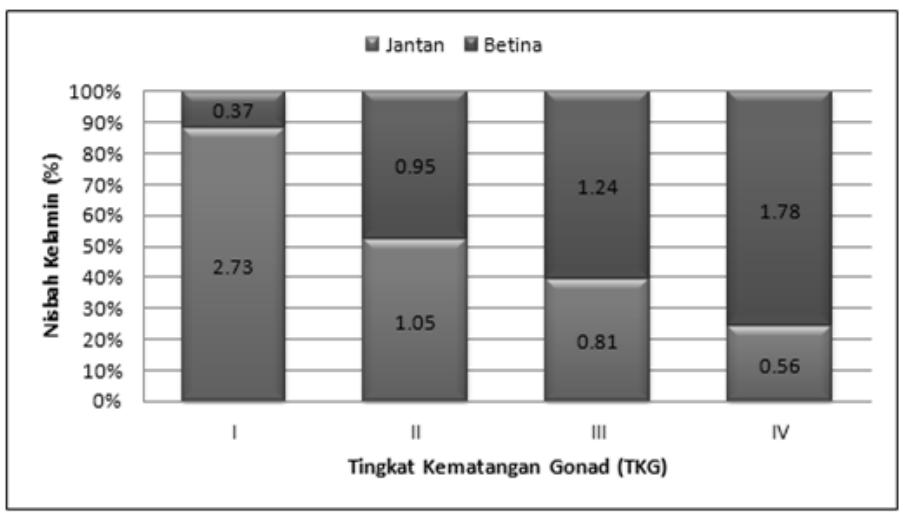

Gambar 4. Grafik nisbah kelamin kerang lumpur (Anodontia edentula Linnaeus, 1758) jantan dan betina berdasarkan tingkat kematangan gonad (TKG) di Pulau Tobea, Kecamatan Napabalano, Kabupaten Muna.

Hal yang sama pula terjadi pada perbandingan jenis kelamin jantan dan betina kerang lumpur berdasarkan tingkat kematangan gonad (TKG), nisbah kelamin jantan dan betina sebesar 1,29: 1,08 (Tabel 2 dan Gambar 4), yang ditunjukkan dengan nilai chi-square sebesar 24,1319. Hal ini berarti bahwa jumlah kerang lumpur jenis kelamin jantan lebih sedikit dibanding jenis kelamin betina pada setiap waktu pengambilan sampel. 
Tabel 3. Nisbah kelamin kerang lumpur (Anodontia edentula Linnaeus, 1758) jantan dan betina berdasarkan stasiun pengambilan sampel (Plot) di Pulau Tobea, Kecamatan Napabalano, Kabupaten Muna

\begin{tabular}{ccccc}
\hline Stasiun pengambilan sampel & \multicolumn{2}{c}{ Jumlah Individu } & \multicolumn{2}{c}{ Nisbah Kelamin } \\
\cline { 2 - 4 } (Plot) & Jantan & Betina & Jantan & Betina \\
\hline I & 119 & 126 & 0,94 & 1,06 \\
II & 169 & 182 & 0,93 & 1,08 \\
III & 127 & 195 & 0,65 & 1,54 \\
\hline Jumlah & 415 & 503 & 0,84 & 1,22 \\
\hline
\end{tabular}

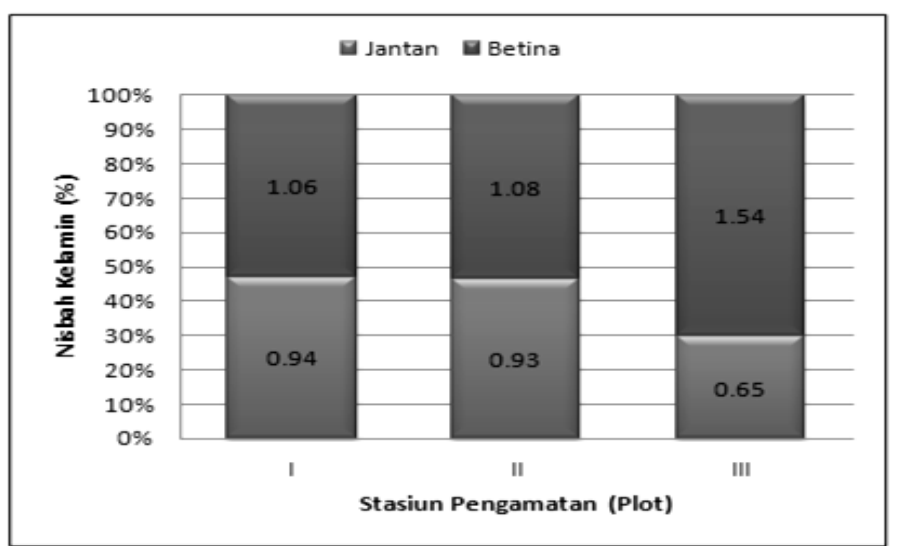

Gambar 4. Grafik nisbah kelamin kerang lumpur (Anodontia edentula Linnaeus, 1758) jantan dan betina berdasarkan stasiun pengamatan (plot) di Pulau Tobea, Kecamatan Napabalano, Kabupaten Muna.

Berdasarkan stasiun pengambilan sampel, nisbah kelamin jantan dan betina sebesar 0,84 : 1,22 (Tabel 3 dan Gambar 5), yang ditunjukkan dengan nilai chi-square sebesar 6,6673. Pada masing-masing nilai chi-square hitung, menunjukkan nilai yang lebih besar dibanding nilai chi-square tabel pada taraf kepercayaan 0,05 , hal ini berarti bahwa nisbah kelamin antara jantan dan betina menunjukkan perbandingan yang tidak sama (tidak berbanding 1:1).

Berdasarkan uraian tersebut, maka dapat dikatakan bahwa jumlah kerang lumpur jantan yang dikoleksi selama penelitian di daerah Pulau Tobea selalu lebih sedikit daripada kerang lumpur betina baik pada setiap waktu pengambilan, tingkat kematangan gonad, maupun berdasarkan plot pengambilan sampel. Secara umum, nisbah kelamin jantan dan betian di lokasi penelitian tidak seimbang, yakni jumlah individu jantan cenderung tidak sama dengan jenis kelamin betina. Diduga hal ini terjadi karena tekanan eksploitasi yang berlebihan, sehingga mengakibatkan kerang lumpur antara jantan dan betina berada dalam keadaan yang tidak seimbang (Rochmady, 2011). Selain itu, keadaan yang tidak seimbang ini juga pengaruh lingkungan berupa perubahan faktor lingkungan yang dapat mengakibatkan perubahan nisbah kelamin jantan dan betina (Effendie, 1997). Selanjutnya dikatakan bahwa pemijahan organisme, dalam hal ini kerang di alam sangat ditentukan oleh kehadiran individu jantan dan betina pada lokasi yang sama. Kehadiran individu jantan dan betina merupakan suatu faktor penting dalam menunjang kelangsungan suatu populasi di alam, sebab kehadiran individu jantan dan betina cenderung akan memudahkan proses fertilisasi (Effendie, 1997; Natan, 2008).

Untuk spesies yang sama, nisbah kelamin jantan dan betina berada pada perbandingan yang sama, sebagaimana yang dilaporkan oleh Rochmady (2011) di daerah Pesisir Lambiku, Kecamatan Napabalano, Kabupaten Muna. Pada spesies yang sama, dilaporkan oleh Natan (2008) di daerah Teluk Ambon Bagian Dalam (TAD) mendapatkan nisbah kelamin jantan dan betina berada pada keadaan yang tidak seimbang, dimana jenis kelamin betina lebih banyak dibanding jenis kelamin jantan.

Pada beberapa spesies Bivalvia, nisbah kelamin jantan dan betina cukup bervariasi, tetapi pada umumnya menunjukkan nisbah kelamin 
yang cenderung sama (Natan, 2008). Keadaan yang menunjukkan jumlah kelamin betina lebih banyak dibanding dengan jenis kelamin jantan, merupakan salah satu strategi reproduksi populasi untuk meningkatkan peluang keberhasilan reproduksinya. Morton (1983) menyebutkan bahwa pada keadaan normal, rasio kelamin yang berbeda merupakan suatu strategi reproduksi pada keadaan lingkungan tertentu. Lebih lanjut dikatakan bahwa kecenderungan strategi reproduksi seperti ini, terjadi pada lingkungan perairan lentik. Sedangkan individu jantan lebih banyak dibandingkan dengan jumlah individu betina merupakan salah satu strategi reproduksi untuk mengoptimalkan keberhasilan reproduksi pada lingkungan perairan lotik.

\subsection{Ukuran pertama matang gonad}

Ukuran pertama matang gonad menunjukkan periode panjang yang dicapai matang gonad baik pada jenis kelamin jantan maupun betina pada masing-masing lokasi penelitian. Berdasarkan perhitungan ukuran pertama kali matang gonad dengan Metode Spearman-Karber (Udupa, 1986), kerang lumpur jantan di Pulau Tobea mencapai ukuran pertama matang gonad dengan rata-rata panjang cangkang sebesar 39,62 mm pada kisaran panjang 39,2040,04 mm. Untuk jenis kelamin betina, ukuran pertama matang gonad dengan rata-rata panjang cangkang sebesar $39,58 \mathrm{~mm}$, pada kisaran panjang sebesar 39,21-39,96 mm.

Berdasarkan ukuran matang gonad sebenarnya menunjukkan bahwa individu kerang lumpur jantan dan betina di daerah Pulau Tobea masing-masing sebesar $39,7 \mathrm{~mm}$ dan $38,0 \mathrm{~mm}$. Berdasarkan perhitungan maupun berdasarkan ukuran pertama matang gonad sesungguhnya terlihat jelas bahwa individu betina mencapai ukuran pertama matang gonad lebih kecil dibanding dengan individu jantan. Hal yang sama ditemukan oleh Natan (2008) dan Rochmady (2011), bahwa ukuran awal matang gonad jenis kelamin betina lebih kecil dibandingkan dengan individu jantan. Perbedaan ukuran pertama matang gonad memperlihatkan adanya suatu strategi reproduksi dari masingmasing spesies.

Perbedaan ukuran awal matang gonad bisa juga mengindikasikan adanya gangguan lingkungan terhadap aktivitas reproduksi. Berdasarkan hasil yang diperoleh menunjukkan bahwa pematangan individu betina relatif lebih lambat dari individu jantan, hal ini relatif dapat mengakibatkan terjadinya gangguan reproduksi oleh karena ketidak tepatan waktu matang gonad antara individu jantan dan betina (Effendie, 1997).

\section{KESIMPULAN DAN SARAN \\ 4.1. Kesimpulan}

Berdasarkan uraian dalam pembahasan, disimpulkan beberapa hal sebagai berikut, yakni :

1. Nisbah kelamin kerang lumpur antara jenis kelamin jantan dan betina tidak berbanding 1 (satu).

2. Ukuran pertama matang gonad kerang lumpur betina lebih kecil dibanding dengan individu jantan.

\subsection{S a r a n}

Berdasarkan kesimpulan di atas, maka disarankan untuk dilakukan penelitian lebih lanjut dengan interval waktu yang cukup dan perlunya dilakukan tindakan pengelolaan terhadap spesies kerang lumpur.

\section{DAFTAR PUSTAKA}

Brusca, R.C. and GJ. Brusca. 2002. Invertebrata. Saunderland, Sinauer Associated. Inc Publishers. New york. 645-769p.

Carpenter, K.E. and V.H. Niem. 1998. Species Identification Guide for Fishery Purpose. The Living Marine Resources of The Western Central Pacific Volume I, Seaweeds, Corals, Bivalves, and Gastropods. Food and Agriculture Organization of The United Nations. Rome. 250p.

Cosel, R.V. 2006. Taxonomy of tropical West African bivalves. VI. Remarks on Lucinidae (Mollusca, Bivalvia), with description of six new genera and eight new species. Zoosystema 28 (4) : 805-851.

Effendie, M.I. 1997. Biologi Perikanan. Yayasan Pustaka Utama. Yogyakarta. 163p.

Fowler, J. and L. Cohen. 1992. Practical Statistics for Field Biology. John Wiley and Sons. Chichester. Singapore. 
Latale, S.S. 2003. Studi Pendahuluan Ekplorasi Sumberdaya Anodontia edentula Pada Perairan Pantai Desa Passo Teluk Ambon Bagian Dalam. Skripsi. Fakultas Perikanan Universitas Pattimura. Ambon. 58 hal.

Lebata, M.J.H.L. 2000. Elemental sulfur in the gills of the mangrove mud clam Anodontia edentula (Family Lucinidae). Journal of Shellfish Research 19(1): 241-245.

Lebata, M.J.H.L. 2001. Oxygen, sulphide and nutrient uptake of the mangrove mud clam Anodontia edentula (Family : Lucinidae). Marine Pollution Bulletin 11(42): 1133-1138.

Lebata, M.J.H.L. and J.H. Primavera. 2001. Gill structure, anatomy and habitat of Anodontia edentula; evidence of endosybiosis. Journal of Shellfish Research, 20(3): 1273 - 1278.

Morton, B. 1983. The Molusca. Volume 6; Ecology Mangrove Bivalvia. Academic Press, Inc. Orlando, New York. pp $77-130$.

Natan, Y. 2008. Studi Ekologi dan Reproduksi Populasi Kerang Lumpur Anodontia edentula Pada Ekosistem Mangrove Teluk Ambon Bagian Dalam. Disertasi. Program Studi Ilmu dan Teknologi Kelautan. Institut Pertanian Bogor. Bogor. 179 hal.

Poutiers, J.M. 1998. Bivalves (Acephala, Lamellibranchia, Pelecypoda), pp 123-362. In Carpenter, K.E and V.H. Niem. 1998. FAO Species Identification Guide for Fishery Purposes. The Living Marine Resources of The Western Central Pacific 1. Seaweeds, Corals, Bivalves and Gastropods. Rome. 686p.

Rochmady. 2011. Aspek Bioekologi Kerang Lumpur Anodontia edentula Linnaeus, 1758 di Perairan Pesisir Kabupaten Muna. Tesis. Program Studi Ilmu Perikanan, Program Pascasarjana, Universitas Hasanuddin. Makassar.

Rochmady, Andy Omar, S.B., Tandipayuk, L.S., 2011a. Perbandingan Karakter Morfometrik Kerang Lumpur Anodontia edentula Linnaeus, 1758 di Pulau Tobea dan Pesisir Lambiku, Kecamatan Napabalano, Kabupaten Muna. Makalah Ilmiah pada Pertemuan Ilmiah Tahunan (PIT) VIII Ikatan Sarjana Oseanologi Indonesia (ISOI) pada tanggal 25-27 September. Makassar. Hal 119.

Rochmady, Andy Omar, S.B., Tandipayuk, L.S., 2011b. Analisis Perbandingan Pertumbuhan Populasi Kerang Lumpur Anodontia edentula Linnaeus, 1758 di Perairan Kepulauan Tobea dan Lambiku, Kecamatan Napabalano, Kabupaten Muna. Fakultas Pertanian, Universitas Muhammadiyah Maluku Utara. Jurnal Ilmiah Agribisnis dan Perikanan AGRIKAN, Volume 4 Edisi 2. Ternate. 14-21p.

Sugiyono. 2006. Statistika Untuk Penelitian. Penerbit Alfabeta. Bandung.

Sjafaraenan. 2011. Pengaruh Konsumsi Daging Kerang Semele sp. Terhadap Kadar Estradiol Pada Wanita Perimenopause. Disertasi. Program Pascasarjana, Universitas Hasanuddin. Makasaar.

Taylor, J.D. and E.A. Glover. 2000. Functional anatomy, chemosymbiosis and evolution of the Lucinidae. Geological Society, London, Special Publications; 2000; v. 177; p. 207-225; http://sp.lyellcollection.org/cgi/content/abstract/177/1/207].

Taylor, J.D. and E.A. Glover., 2004. Systematic revision of Australian and Indo-Pacific Lucinidae (Mollusca: Bivalvia): Pillucina, Wallucina and descriptions of two new genera and four new species. Records of the Australian Museum 53(3): 263-292.

Taylor, J.D. dan E.A. Glover., 2007. Diversity of chemosymbiotic bivalves on coral reefs: Lucinidae (Mollusca, Bivalvia) of New Caledonia and Lifou. Zoosystema 29 (1) : 109-181.

Udupa, K.S. 1986. Statistical method of estimatig the size at first maturity in fishes. Fishbyte 4 (2): 8-10. 